\title{
Bioetiikan queer-feministisestä tulkintakehyksestä
}

\author{
Tiia Sudenkaarne
}

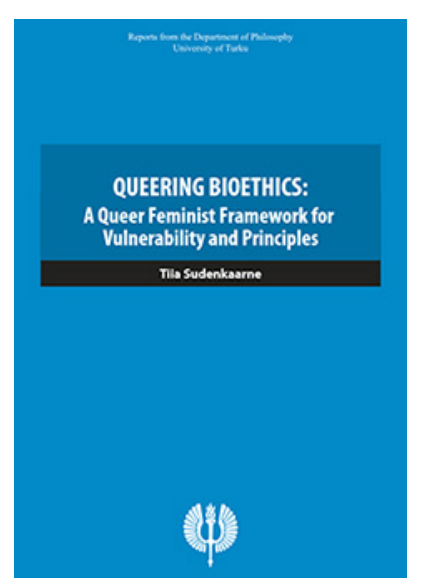

Tiia Sudenkaarne esitti artikkeliväitöskirjansa Queering Bioethics: A Queer Feminist Framework for Vulnerability and Principles julkisesti tarkastettavaksi 28.8.2021 Turun yliopiston filosofian oppiaineessa. Opponenttina toimi professori Jamie Nelson (Michigan State University) ja kustoksena yliopistonlehtori Helena Siipi (Turun yliopisto).

Väitöstutkimuksen artikkelien julkaisutiedot löytyvät lektion kirjallisuusluettelosta. Väitöksen johdanto on sähköisenä luettavissa osoitteessa http://urn.fi/URN:ISBN:978-951-29-8507-4. Lisäksi Sudenkaarne hyödyntää lektiossaan suomenkielisiä, väitöstutkimuksen ulkopuolisia julkaisujaan väitöstutkimuksen teemoista.
Olen hyvin iloinen siitä, että olemme voineet kokoontua tänään tänne näinkin sankoin joukoin ottaen huomioon vallitsevan koronakriisin, joka on tavalla tai toisella koskettanut meistä jokaisen elämää. On kuitenkin syytä panna merkille, että pandemian kaltaiset kriisit ovat omiaan syventämään jo vallitsevia eriarvoisuuksia, jotka ehkä paikantuvat mutta eivät rajoitu terveysturvallisuuskysymyksiin. Siksipä onkin mitä sopivinta keskustella nyt juuri bioetiikasta.

\section{Mitä bioetiikka on?}

Bioetiikka tutkii ja selvittää moraalis-yhteiskunnallisia kysymyksiä, jotka nousevat erityisesti lääke- ja biotieteiden kehityksestä ja joilla on myös valtasuhteisiin liittyviä ulottuvuuksia (Häyry 2014; Sudenkaarne 2021,3). Englanninkielinen artikkeliväitöskirjani koostuu johdannosta ja neljästä tutkimusartikkelista. Siinä tarkastelen, miten kriittiset feministiset ja queernäkökulmat bioetiikan peruskäsitteisiin, kuten oikeudenmukaisuuteen ja haavoittuvuuteen, voivat rikastuttaa bioetiikan teoriaa, metodologiaa ja käytäntöä sekä laajemmin palvella yhteiskunnallista muutosta. Keskeinen johtopäätökseni on, että cis- ja heteronormatiivisuudeksi nimeäni oletus hyvän elämän ehdoista ja ihmisyydestä on eettisesti kestämätön, mitä tutkimuksessani esimerkein perustelen. Tästä johtopäätöksestä seuraa, että on pyrittävä vahvistamaan bioetiikan queer-feminististä tulkintakehystä, jota 
jo tässä väitöstutkimuksessani hahmottelen. Vielä korkeampana tavoitteena on pyrkiä kehittämään queer-bioetiikkaa moraaliteoriana, jollaisena sen luojat Lance Wahlert ja Autumn Fiester (2012, iii) sen potentiaalisesti näkevät (Sudenkaarne 2021).

Tutkimukseni avainkäsitteitä on cis- ja heteronormatiivisuus. Cis-normatiivisuudella tarkoitetaan ajatusta kaksinapaisesta eli binäärisestä sukupuolijärjestelmästä. Sen navat ovat mieheydeksi ja naiseudeksi kutsutut positiot, jotka ovat sisällöltään vastakkaisia. Binäärisessä sukupuolijärjestelmässä kaikkien ihmisten oletetaan sijoittuvan jompaankumpaan positioon, ja sijoittumisen ajatellaan perustuvan ongelmattomasti fysiologiaan, jota ilmennetään kulttuurisesti sovituin merkein. (vrt. Tainio 2013, 19; sukupuolijärjestelmästä ks. Liljeström 1996.) Esimerkiksi henkilö, jolla on pitkät hiukset ja rinnat, oletetaan länsimaisessa kontekstissa naiseksi. Normatiivinen elementti sukupuolijärjestelmässä tarkoittaa edellistä esimerkkiä jatkaakseni ei vain sitä, että kaikilla naisilla oletetaan olevan rinnat, vaan myös, että vain naisilla tulisi olla rinnat, ja miehillä taas ei. Siten normi oikeuttaa joukon terveydenhuollon naiserityisiä projekteja, vaikkapa rintasyövän ehkäisyn, jonka toivotaan puhuttelevan yhtenäistä joukkoa samanlaiseksi oletettuja naisia, mutta toisaalta myös paineen muokata rintoja tietyn kauneusihanteen mukaan esteettisellä kirurgialla. Koska rintojen läsnä- tai poissaolo ei lopulta ole välttämätön tai edes riittävä ehto naisena olemiselle - harva kyseenalaistaa rintansa syövän takia menettäneen cis-naisen sukupuolistatusta - cis-normatiivisuus perustuu lopulta epämääräisille, luonnollistetuille oletuksille sukupuoliomaisuuksista, jotka ovat rakentuneet toisilleen vastakkaisiksi (Sudenkaarne 2018c, 205-206).

Heteronormatiivisuus kytkeytyy juuri kaksinapaiseen sukupuolijärjestelmään: se olettaa, että kaikki ihmiset ovat joko miehï tai naisia, jotka lisääntymisviettinsä ohjaamina tuntevat toisiinsa seksuaalista halua. Näin oikeutetaan esimerkiksi yhteiskunnallisten instituutioiden järjestäminen heteronormin mukaan (Sudenkaarne 2018c, 206). Cis- ja heteronormatii- visuus on tuottavaa, biologista, lääketieteellistä ja seksuaalista tieto-valtaa, joka pyrkii järjestämään kaikki ruumiit, halutja sosiaaliset identiteetit kaksinapaiseen, täydentämisperiaatteen mukaiseen malliin (Butler 1990, 5; 151)

Vaikka cis- ja heteronormatiivisuus luo eettisesti kestämättömiä käytänteitä hahmottaa ja kohdata sukupuolen ja seksuaalisuuden moninaisuutta, on oleellista huomata, että sen rajoittavat vaikutukset kohdistuvat myös cissukupuolisiksi ja heteroseksuaaleiksi identifioituviin henkilöihin: sukupuolistereotypiat esimerkiksi miehistä tunteettomina seksimaanikkoina tai naisista hysteerisinä himoshoppaajina paitsi vastaavat vain murto-osan sukupuolikokemusta, myös pyrkivät normalisoimaan epäoikeudenmukaisuutta. Ne ovat myös inhimillisen kukoistuksen esteenä: sukupuolistereotypiat voivat estää lahjakasta poikaa tulemasta taitoluistelijaksi ja ajaa älykästä tyttöä piilottelemaan matemaattisia lahjojaan. Bioeettisesti haavoittavimmillaan cis- ja heteronormatiivisuus oikeuttaa esimeriksi intersukupuolisena syntyvän lapsen sukuelinten silpomisen sen varmistamiseksi, että hän myöhemmin kykenisi heteroyhdyntän joko antavana tai ottavana osapuolena - ja yleensä ottavana, koska 'reikä on helpompi tehdä kuin tappi' (Toriseva 2017,24-26). Näin fysiologinen mahdollisuus heteroyhdyntään samaistetaan hyvään elämään (emt). Normatiivisuus myös häivyttää ristiriidan esimerkiksi transsukupuolisen henkilön lisääntymiskyvyttömyysvaatimuksen ja cis- ja hetero-oletettujen henkilöiden hyvin tiukkojen sterilisaatioehtojen välillä.

\section{Queer-feministisen tulkintakehys bioetiikan haastajana}

Trans- ja intersukupuolisten ihmisten negatiiviset potilaskokemukset ja rooli tiedon tuottajina pyritään yhä kiistämään (Nelson 1998; 2012; Stryker 2006). Potilaskokemusten ristiriitaisuudesta huolimatta lääkärit kokevat usein toimivansa hyväntahtoisesti ja mahdollistavansa hyvän elämän peruuttamattomia päätöksiä tehdessään; valtaosa lääkäreistä esimerkiksi
SQS

$1-2 / 2021$ 
kokee antavansa potilaalleen parasta mahdollista hoitoa suositellessaan 'tappi tai reikä' -tyyppistä kirurgiaa intersukupuoliselle lapselle (Hester 2004; Toriseva 2017). Oleellista on hahmottaa, että päätösten taustalla on usein virheellinen oletus hetero- ja cis-normatiivisuudesta hyvän elämän välttämättömänä ehtona (ks. myös Toriseva 2017). Oletukselle ei ole empiirisiä tai moraalisia perusteita, eikä cis- ja heteronormatiivisuus ole minään historian ajanjaksona tai missään kulttuurissa ollut ihmiselämän rikkauden mitta. Erityisesti trans- ja intersukupuolisuuden kokemustieto on kiistatta osoittanut, miten oletus kaventaa usein peruuttamattomasti inhimillistä kukoistusta (Wahlert \& Fiester 2014; Toriseva 2017; Feder 2014; Hester 2004; Marsh 2006; Morris 2006; Aspinall; Abelow Hedley 2006; Nelson 1998; 2012; ETENE 2016). Näin ollen ainoa bioeettisesti kestävä ratkaisu tuntuisi olevan cis- ja heteronormatiivisuudesta luopuminen (Sudenkaarne 2018c, 218-219). Sen tilalle ehdotan tutkimuksessani queer-feminististä tulkintakehystä, joka yhdistää feministisen bioetiikan ja queer-bioetiikan näkemyksiä ja asettaa normiksi sukupuolen ja seksuaalisuuden moninaisuuden.

\section{Mitä feministinen bioetiikka on?}

Bioetiikan ammatillistumisen myötä sen piirissä on kasvanut kriittinen näkemys, jonka mukaan se on kadottamassa juurensa osana ihmisoikeusliikettä. Jos se unohtaa marginaaliset ryhmät ja uusintaa konservatiivisia kysymyksenasetteluita, se on vaarassa tulla osaksi sortavia järjestelmiä pikemminkin kuin haastaa niitä (Donchin \& Scully 2015; Donchin \& Purdy 1999; Holmes 1999; Lindemann 2007; Sudenkaarne 2021, 39). Kriitikoiden mukaan bioeettisessä teorianmuodostuksessa uhkaavat korostua etuoikeutettujen näkökulmat. 1980-luvulta lähtien etenkin feministinen ajattelu on kunnostautunut bioetiikan kritiikissä tuoden keskiöön lukuisia sukupuoleen kytkeytyviä terveyseroja sekä luokkaan ja rodullistamiseen kytkeytyviä eriarvoisuuksia terveydenhoidossa. (Donchin \& Scully 2015; Donchin \& Purdy 1999; Holmes 1999; Lindemann 2007; Sudenkaarne 2021, 39-40). 1990-luvulla nämä kriittiset äänet olivat muodostaneet feministisen bioetiikan kaanonin, joka pystyi tarjoamaan metodologisia analyysejä sukupuolen, rodun, vallan ja epäoikeudenmukaisuuksien kytköksistä erilaisissa konteksteissa. Feministisen bioetiikan keskeisiä taustavaikuttajia ovat 1900-luvun jälkipuoliskon naisten terveysliike sekä niin kutsuttu toisen aallon feminismi. Ne nostivat esiin ja tutkivat naiserityisiksi miellettäviä, marginaalistettuja kysymyksiä kuten mahdollisuuksia käyttää ehkäisyä ja saada turvallinen raskaudenkeskeytys, sekä kritisoivat naisten seksuaalisuuden kontrollia (Donchin \& Scully 2015; Donchin \& Purdy 1999; Holmes 1999; Wolf 1996; Sudenkaarne 2021, 39-40).

Feminististä bioetiikkaa kehittäneen Hilde Lindemannin (2007, 117; Sudenkaarne 2021,40) mukaan feminismin tärkein anti bioetiikalle on ollut niin kutsutun biologisen sukupuolen ja sosiaalisen sukupuolen ympärille kietoutuvien valtasuhteiden hahmottaminen lääke-ja biotieteissä sekä terveydenhuollon käytänteissä, järjestelmissä ja teorioissa. Tätä hahmotusta on oleellisesti laajentanut postmoderni feminismi ja queer-teoria, joiden myötä biologisuus hahmottuu sukupuolitetuksi fysiologiaksi, joka on yhtä kontekstisidonnainen kuin niin kutsuttu sosiaalinenkin sukupuolikin. Feministinen bioetiikka ja queer-bioetiikka tuovat kuitenkin toistuvasti esille, miten problematisoiduilla käsitteillä kuten sukupuolella voi olla hyvin suoraviivaisia seurauksia, jotka sekä kytkeytyvät muihin eriarvoisuuksiin että tuottavat niitä.

Keskeinen feministisen bioetiikan ja queer-bioetiikan yhtymäkohta onkin kiinnostus eriarvoisuuteen ja sitä kautta bioeettiseen oikeudenmukaisuuteen. Anne Donchin ja Laura Purdy $(1999,2)$ näkevät feministisen bioetiikan yhdistävänä eetoksena oikeudenmukaisuustyön. Halu edistää sosiaalista oikeudenmukaisuutta ja pyrkiä purkamaan sukupuoleen, ro-
SQS

$1-2 / 2021$ 
tuun, sukupuolen ja seksuaalisuuden moninaisuuteen sekä kyvykkyyteen pohjaavaa syrjintää tarjoaa mahdollisuuden identiteetin, relativismin ja essentialismin ongelmat ylittävään solidaarisuuteen. Tällainen lähestymistapa myös luo politiikkoja ja uudistaa teoriaa: ideat ja käytänteet nousevat eletystä kokemuksesta ottamalla erot eettisesti kestävästi haltuun mutta säilyttäen yhteiset päämäärät (Donchin \& Purdy 1999, 4-6; ks. myös Nyrövaara 2011; Sudenkaarne 2021, 48).

Teoreettisesta näkökulmasta oikeudenmukaisuuden painotus tarkoittaa siirtymää yleistysten ja ajatuskokeiden maailmasta elettyjen, ruumiillisten, paikantuneiden kokemusten tarkasteluun. Hilde Lindemannin (2007) ja Donna Harawayn (1988) tavoin Donchin ja Purdy (1999, 4-6; Sudenkaarne 2021, 48) näkevät keskeisenä vallan ja yksilöllisen toimijuuden ristivedon: yhtäältä valta marginalisoi ja määrittelee yksilöllisen toimijuuden ehtoja, toisaalta yksilöllinen toimijuus rakentuu myös marginalisoivan vallan ulottumattomissa (Sudenkaarne 2021,48). Feministinen bioetiikka pyrkii teoretisoimaan näitä yksilöllisiä toimijuuksia ja tarkastelemaan niiden konteksteista nousevia eettisiä ongelmia eroja kunnioittaen mutta vaipumatta relativismiin, jossa normatiivisesta arvioinnista luovutaan ja kaikki käy (Donchin \& Purdy 1999, 6-8; Sudenkaarne 2021, 48-50). Omassa työssäni olen asemoinut queer-bioetiikan täydentämään tätä projektia.

\section{Mitä queer-bioetiikka on?}

Yhtäältä queer-bioetiikalla tarkoitetaan lesboihin, homoihin, biseksuaalisiin, trans- queer- sekä intersukupuolisiin henkilöihin sekä muihin sukupuoleltaan ja seksuaalisuudeltaan moninaisiin henkilöihin liittyviä erityisiä bioeettisiä kysymyksiä. Sellaisia ovat esimerkiksi juuri transsukupuolisuudessa sukupuolen korjaamiseen ja intersukupuolisuudessa niin kutsuttuun sukupuolen määräytymiseen liittyvät juridis-medikaaliset käytänteet, tai vaikkapa samaa sukupuolta olevien parien oikeus avusteiseen lisääntymiseen. Toisaalta queer-bioetiikka jäljittää ja haastaa sukupuolen ja seksuaalisuuden määritelmiä (Sudenkaarne 2018, 220; Sudenkaarne 2021).

Queer-bioetiikan pioneerien Lance Wahlertin ja Autumn Fiesterin (2012, iii-iv; Sudenkaarne 2018, 221) mukaan queer-bioetiikka tutkii sukupuolen ja seksuaalisen moninaisuuden kysymyksiä asettamalla seksuaali- ja sukupuoli-identiteetin bioeettisten analyysien keskeisiksi tulkintalähtökohdiksi purettaessa ja uudelleen neuvoteltaessa normaaliutta. Queer-bioetiikkaan liittyykin oleellisesti eettisen arvioinnin elementti: se tarkastelee kriittisesti olemassa olevia lääketieteellisiä käytänteitä sekä toiminta- ja tutkimustapoja. Queer-bioetiikka haluaa nostaa merkittävinä esiin niin kutsutut'vähemmistökysymykset', kyseenalaistaa vallitsevia merkityksellistämisjärjestelmiä ja normatiivisuuden oikeutusta, luoda rohkeita poikkitieteellisiä yhteyksiä sekä rakentaa vastarintastrategioita syrjiville ja epäoikeudenmukaisille käytänteille niin potilas-läkäri-kohtaamisissa kuin järjestelmä- ja tutkimustasollakin. Wahlert ja Fiester $(2012$, iv) toivovat queer-bioetiikan kehittyvän moraaliteoriaksi. Suhtaudun queer-bioetiikan moraaliteoreettiseen potentiaaliin myönteisesti, mutta näen sen vaativan jatkokehittelyä (Sudenkaarne 2018, 221; Sudenkaarne 2021).

Koska jopa hyvää tarkoittavat, eriarvoisuutta purkamaan pyrkivät lhbtqi+ -tapausanalyysit saattavat lisätä cis- ja heteronormista poikkeamisen stigmaa, Wahlert ja Fiester (2014, S62; Sudenkaarne 2018, 11-12) ovat kehittäneet metodologisen työkalun, queer-bioeettisen arviointilistan, jota käytän myös tämän väitöstutkimuksen kolmessa artikkelissa. Arviointilistan kysymykset pyrkivät luomaan metodologian epäkohtiin puuttumiselle. Niitä voi käyttää niin kliinisen työn arvioimiseen kuin bioeettisen tutkimuksen meta-analyysiin. Käytännöllisenä ja teoreettisena työkaluna arvioinnin tarkoitus on vastata nykyistä paremmin lhbtqi+-henkilöiden kliinisiin ja biotieteellisiin tarpeisiin. Arvioinnin tarkoitus on myös luo-
SQS

$1-2 / 2021$ . 
da queer-analyysin kategorioita, jollaisia väitöstutkimuksessani tarjoan erityisesti queer-haavoittuvuuksien kautta (Sudenkaarne 2018, 11-12).

\section{Bioetiikan periaatteet ja queer-feministinen tulkintakehys}

Väitöstutkimuksen johdannossa pohdin erityisesti periaatteisiin nojaavaa etiikkaa, joka on keskeinen bioetiikan suuntaus niin akateemisessa tutkimuksessa kuin lääketieteen käytäntöjä, rakenteita ja hoitosuosituksiakin arvioitaessa (Sudenkaarne 2021, 34). Periaatteiden ajatellaan yhtäältä nousevan moraaliteorioista tai toisaalta nojaavaan niin kutsuttuun yleiseen moraalikäsitykseen. Esitän, että molemmissa käsityksissä ydinajatus on, että periaatteiden kautta tavoitetaan moraalisesti merkittäviä elementtejä, jotka ohjaavat eettistä päätöksentekoa Tunnetuimpia periaatteita ovat autonomian kunnioittaminen, hyvän tekeminen, pahan tekemisen välttäminen ja oikeudenmukaisuus. Jälkimmäinen määritellään usein nähdäkseni riittämättömästi riskien ja hyötyjen reiluksi jakaantumiseksi. Queer-feministisen tulkintakehyksen keskeinen tarkoitus onkin syventää bioeettisen oikeudenmukaisuuden määrittelyä ja analyysiä (Sudenkaarne 2021, 34-35).

Queer-feministisestä näkökulmasta arvioituna sen paremmin bioetiikassa kuin lääketieteenkään etiikassa riskien, kustannusten ja hyötyjen jakaantumista ei tarkastella reilusti (Wolf 1996; Holmes 1999; Wahlert \& Fiester 2014). Keskeinen queer-feministinen kritiikki onkin, että niin kutsuttua yleistä moraalikäsitystä hyödyntävät lähestymistavat samaistavat moraalisen objektiivisuuden abstraktiin rationaalisuuteen, joka on inhimilliselle elämälle ja sen monimuotoisuudelle vierasta ja taipuvainen myötäilemään etuoikeutetumpien asemaa. Tästä seuraa usein ihmisten mieltäminen riippumattomiksi, vaikka tosiasiassa esimerkiksi toimijuutta määrittävät lukuisat valtasuhteisiin liittyvät reunaehdot ja materiaaliset olosuhteet, kuten vaikkapa varallisuus tai koulutus. Yleiseen moraaliin vetoavissa nä- kemyksissä ei myöskään yleensä haluta ottaa moraaliteoreettista kantaa, vaikka yleiseen moraalin vetoamista voi jo itsessään pitää moraaliteoreettisena kantana. Ongelmaksi kuitenkin jää, miten yleisiä periaatteita pitäisi määritellä ja soveltaa. Usein niitä päädytäänkin hyödyntämään vain osittain (Tong 1996, 69; Clouser \& Gert 1990, 223; Donchin 2001, 366; Sudenkaarne 2021, 34-35).

Väitöstutkimuksessani erittelen, miten juuri epämääräinen suhde moraaliteoriaan on bioeettisten periaatteiden käyttämisen keskeinen ongelma (Sudenkaarne 2021, 73). Ilman aukikirjoitettua ja siten tarkasteltavissa olevaa tulkintakehystä voidaan periaatteita sovellettaessa päätyä hyvin monenlaisiin tulkintoihin. Vaikka teoriapohjan ongelman voi pyrkiä ratkaisemaan menetelmävalinnalla, esimerkiksi laajan reflektiivisen tasapanoin menetelmällä kuten usein ehdotetaan, ei pelkkä menetelmävalinta riitä takamaan sitä, että seksistiset, rasistiset ja hierarkkiset oletukset purkautuvat eettisesti kestämättöminä, minkä tarpeen feministifilosofit ovat kiistatta osoittaneet (Lloyd 1984; Code 2007; Lugones 1994; Anzaldúa 1999). Näin ollen esitän, että queer-feministinen tulkintakehys voisi olla eettisesti kestävän moraaliteoreettisen kytköksen (Sudenkaarne 2021,73).

Periaatteellisen lähestymistavan kiivaimmat kriitikot ovat ehdottaneet periaatteiden hylkäämistä kokonaan. Itse kallistun kannattamaan näkemystä, jonka mukaan periaatteita ei tule hylätä, vaan niiden määritelmää, taustateoriaa ja toteutumisen tarkastelua kehittää (vrt. Purdy 1992, 10; Donchin 2001; Sudenkaarne 2021,36), sillä niiden kautta on vakiintunut tiettyjen perustavanlaatuisten eettisten ristivetojen tarkastelu. Periaatteet tai arvot, kuten oikeudenmukaisuus, ovat puolustettavissa vain, jos etiikka nähdään sosiaalisena järjestelmänä, joka pyrkii aidosti edistämään kaikkien hyvinvointia. Tällöin on oleellista hahmottaa hyvinvointiin liittyviä eriarvoisuuksia. Bioetiikassa tähän kuuluu marginaalistettujen ryhmien kuten naisten, lhbtqi+ -henkilöiden sekä rodullistettujen ih-
SQS

$1-2 / 2021$ . . 
misten erityistarpeiden tunnistaminen ja niihin vastaaminen myös siksi, että ne kytkeytyvät perustavalaatuisiin moraalisiin ongelmiin. Periaatteet voi nähdä myös siltana yhteistoimintaan. (Purdy 1992, 10-11; ks. myös Macklin 2003). On myös huomattava, että erojen hahmottaminen on sovitettavissa yhteen periaatteellisen tarkastelun kanssa, eivätkä periaatteet edellytä ihmiselämälle vierasta yleistämistä. (Wolf 1999, 74). Samaan aikaan on kuitenkin äärimmäisen tärkeää muistaa, että periaatteellinen lähestymistapa ei riitä takaamaan, että periaatteet kiistatta toteutuisivat tai että ne olisivat tasapainossa, kuten väitöstutkimuksenikin omalta osaltaan todistaa. Siksi bioetiikassa tarvitaan välttämättä tarkastelukehyksiä, jotka ovat sekä tarpeeksi kriittisiä tuodakseen esiin epäoikeudenmukaiset valtasuhteet että tarpeeksi vakuuttavia saadakseen noista valtasuhteista hyötyvät luopumaan asemastaan (Tong 2013,29-30; Sudenkaarne 2021, 37.) Toivon queer-feministisen tulkintakehyksen osaltaan vastaavan tähän haasteeseen (Sudenkaarne 2021, 36-37).

\section{Väitöstutkimuksen artikkelit}

Selvitän seuraavaksi, miten edellä esitetyt laajemmat keskustelut kytkeytyvät väitöstutkimukseni neljään artikkeliin. Ensimmäisessä artikkelissa "Considering Unicorns: Queer Bioethics and Intersectionality” tarkastelen käsiteanalyyttisesti queer-bioetiikan rakentumista ja sen suhdetta intersektionaalisuuden teoriaan eli useiden samanaikaisten syrjinnälle altistavien akseleiden läsnäoloon (Sudenkaarne 2018a). Tästä nousevat identiteetin, essentialismin ja relativismin ongelmiksi nimeämäni yleisfilosofiset jännitteet, joita edellä käsittelin vallan ja yksilöllisen toimijuuden ristivetona: kuinka peräänkuuluttaa muutoksen politiikkoja, jos olemme kaikki perustavanlaatuisesti erilaisia ja kaikki näkemyksen ovat yhtä puollettavia (Sudenkaarne 2021, 12). Väitöstutkimuksen johdannossa palaan näihin ongelmiin ja ehdotan niihin yhdeksi ratkaisuksi haavoittuvuuden käsitteen kautta avautuvaa kerroksellisuutta tiettyjen haavoittuvuuksien hahmottamiseen (Sudenkaarne 2021, 28-34). Tällöin tietyt haavoittuvuudet hahmottuvat kytkeytyneinä tiettyihin ominaisuuksiin kuten sukupuoleen, mutta samalla käsitetään haavoittuvuuden dynamiikka altistumisena, ei olemusta leimaavana haavoittuvuutena ja voimattomuutena

Toisessa artikkelissa "Queering Bioethics: A Queer Biothics Inventory of Surrogacy” siirryn soveltamaan queer-bioetiikkaa sijaissynnyttämisen bioeettisessä keskustelussa (Sudenkaarne 2018b). Metodologisina työkaluina käytän käsiteanalyysiä ja queer-bioeettistä kysymyslistaa (Queer Bioethics Inventory) (Wahlert \& Fiester 2014, S62). Analyysini tuloksena esitän, että cis- ja heteronormatiivisuus saattaa vääristää bioeettistä arviointia: se voi estää aitojen eettisten ongelmien, kuten pulmallisen kaupallisuuden erottamisen sen itsensä luomista ongelmista, kuten näkemyksestä, että sijaissynnyttäminen kohdun viasta tai puutteesta kärsivän heteroavioparin lapsettomuushoitona olisi eettisesti kestävin sijaissynnytysjärjestely (Sudenkaarne 2021, 13). Artikkeli syventää pro gradu -työssäni Kohtupolitiikkaa: feministisen bioetiikan ja queer-bioetiikan näkökulmia sijaissynnyttämiseen aloittamaani pohdintaa (Junnonaho 2014).

\section{Queer-haavoittuvuuksien metodologia}

Kolmannessa väitösartikkelissa "Queering Vulnerability: A Layered Bioethical Approach" kehitän queer-bioetiikan teoriaa ja metodologiaa edelleen yhdistämällä queer-bioeettisen kysymyslistan keskeiset elementit edellä mainittuun feministisen bioetiikan kerrokselliseen haavoittuvuuden teoriaan ja käsitteellistän näin kiintymykseen, intiimiyteen, toimijuuteen ja eettiseen kestävyyteen kytkeytyvät queer-haavoittuvuuden kerrokset (Sudenkaarne 2019). Kiintymykseen liittyvät queer-haavoittuvuudet (troubled kinship) hahmottuvat analysoimalla, miten lääkäri tai muu
SQS

$1-2 / 2021$

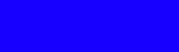

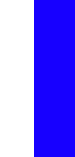


hoidosta vastaava henkilö huomioi yksilön läheissuhteita - onko eicis-heteronormatiivisille perhe- ja läheissuhteille tilaa? Häiritsevyys tai hankaluus (troubled) viittaa siihen, että läheis- tai kiintymyssuhteiden arvottaminen perustuu cis- ja heteronormatiivisuuteen eikä tieteelliseettiseen arviointiin. Häiritseminen tarkoittaa siis cis- ja heteronormatiivisten käytäntöjen kyseenalaistamista, hankaloittamista ja kumoamista. Häiritsevän kiintymyksen kerroksen keskeinen funktio on sen oletuksen kyseenalaistaminen, että kiintymys rakentuu saumattomasti cis- ja heteronormatiivisuuden piirissä. Queer-kiintymys siis häiritsee, hankaloittaa ja pysäyttää cis- ja heteronormatiivisuuden logiikkaa (Parhi \& Sudenkaarne 2020, 147-148; Sudenkaarne 2021, 68).

Intiimiyteen liittyvät queer-haavoittuvuudet syntyvät epäkunnioittavasta kiinnostuksesta (interrogatory intimacy) sukupuoleltaan ja seksuaalisuudeltaan moninaisten henkilöiden seksielämään, fysiologiaan ja mielensisältöihin. Intiimiyteen liittyviä queer-haavoittuvuuksia voi hahmottaa esimerkiksi arvioimalla, onko tapauksessa hoidon kannalta tarpeetonta seksuaalisten tekojen kuvailua. Intiimiyden haavoittavuutta arvioitaessa pyritään myös hahmottamaan seksuaalisten tekojen arvottamista suoraan tai epäsuorasti esimerkiksi homo-hetero-akselilla tai 'holtittomuutena'. Tietyt aktit voidaan mieltää terveyttä uhkaaviksi tai psyykeä vahingoittaviksi moralistisin perustein (Parhi \& Sudenkaarne 2020, 148; Sudenkaarne 2021, 68).

Queer-toimijuuteen ( queer agency) liittyviä haavoittuvuuksia analysoidaan sukupuolen ja seksuaalisuuden moninaisuuden sekä toimijuuden suhteista esimerkiksi lhbtqi+-potilaiden hoidon kirjauksissa ja käytännöissä. On myös keskeistä, miten normista poikkeava ruumiillisuus ja siihen liittyvä toimijuus mielletään. Usein queer-toimijuus kyseenalaistuu tai jää näkymättömiin tiedontuotannollisissa malleissa, jotka perustuvat sukupuolen ja seksuaalisuuden moninaisuuden patologisointiin (Parhi \& Sudenkaarne 2020, 148; Sudenkaarne 2021, 68).
Eettiseen kestävyyteen (ethical sustainability) liittyvät queer-haavoittuvuudet märittyvät oleellisesti hetero- ja cis-normatiivisuuteen pohjaavasta arvottamisesta sekä sen vaikutuksista tapaukseen, kirjaukseen tai hoitosuositukseen (Parhi \& Sudenkaarne 2020, 148; Sudenkaarne 2021, 68). Keskeistä on myös hahmottaa, perustuuko tapauksen kiinnostavuus yksinoman sukupuolen ja seksuaalisuuden moninaisuuteen. Onko lhbtqi+ihmiset kuvattu stereotyyppisesti? Entä vahvistaako tapaus negatiivisia käsityksiä sukupuolen ja seksuaalisuuden moninaisuudesta? Eettiseen kestävyyteen liittyviä queer-haavoittuvuuksia hahmotetaan siis analysoimalla eettisen merkityksellistämisen ja päätöksenteon rakentumista yhtäältä lhbtqi+ja toisaalta cis- ja heteronormatiivisissa tapauksissa ja niiden kyseenalaisia käytäntöjä tai arvostelmia paikantamalla. Eettiseen kestävyyteen liittyviä queer-haavoittuvuuksia arvioitaessa voi tarkastella myös, muuttuuko tulkinta, kun tapauksen keskushenkilö on lhbtqi+ -ihminen tai cis- ja heteronormia vastaava henkilö (Parhi \& Sudenkaarne 2020, 148; Sudenkaarne 2021, 69). Lopulta kyse on siitä, rakentuuko cis- ja heteronormatiivisuus eettisen arvioinnin välttämättömäksi ehdoksi, kuten usein käy.

Neljännessä artikkelissa "Queering Medicalized Gender Variance" sovellan luomiani queer-haavoittuvuuden kerroksia sukupuolen moninaisuuden diagnostiikkaan eli ICD-11 ja DSM-V tautiluokituksiin. Niissä molemmissa on aiemmin ollut diagnoosikriteerit homoseksuaalisuudelle ja on yhä sukupuolen inkongruessin tai sukupuolidysforian luokitukset (Sudenkaarne 2020b). ICD on käytössä suuressa osassa maailmaa, Suomi mukaan lukien, DSM taas Pohjois-Amerikassa. Analyysissäni totean, että vaikka parannuksia edellisiin versioihin on tehty, ovat molemmat luokitukset laajemman queer-bioeettisen reformin tarpeessa ja nojaavat epämääräisille metafyysisille käsityksille sukupuolesta (Sudenkaarne 2021, 13).
SQS

$1-2 / 2021$

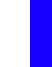
. 


\section{Kohti queer-bioeettistä moraaliteoriaa}

Väitöstutkimukseni keskeinen johtopäätös on, että sukupuolen ja seksuaalisuuden moninaisuuden normin tulisi sisältyä bioeettisiä periaatteita ohjaavaan kehykseen, sillä siten turvataan parhaiten sekä periaatteiden että laajemmin eettisyyden toteutuminen myös lhbtqi+ -tapauksissa (Sudenkaarne 2021). Keskeisiä jatkotutkimuksen tarpeita ovat queer-bioetiikan kehittäminen edelleen moraaliteoriana, queer-haavoittuvuuksien soveltaminen aineistoihin sekä queer-feministisen tulkintakehyksen soveltaminen ja kehittäminen edelleen. Väitöksenjälkeisessä tutkimuksessani Helsingin yliopiston tutkijatohtorina Suomen Akatemian hankkeessa Social Study of Antimicrobial Resistance: Health Care, Animals, and Ethics aionkin jatkaa tätä työtä posthumanistisella eli ihmisen sisältävällä mutta hänen keskeisyytensä kiistävällä otteella kehitellessäni queer-feministisiä näkökulmia antibioottiresistenssistä käytävään bioeettiseen keskusteluun. Queer-bioetiikan moraaliteoriana tulisi nähdäkseni vastata paremmin moninaisten eriarvoisuuksien haasteisiin sekä pyrkiä ratkomaan lisääntymisoikeuksien, lisääntymisoikeudenmukaisuuden ja eko-oikeudenmukaisuuden välisiä ristiriitoja globaalissa mittakaavassa: siis tarjota osaltaan vastauksia aikamme suurimpiin eettisiin kriiseihin antibioottiresistenssistä ilmastonmuutokseen.

\section{Kirjallisuus}

Abelow Hedley, Lisa. 2006. The Seduction of the Surgical Fix. Teoksessa Surgically Shaping Children. Technology, Ethics and the Pursuit of Normality, toimittanut Erik Parens, 43-51. Baltimore, Johns Hopkins University Press.

Anzaldúa, Gloria. 1999. Borderlands/La Frontera: The New Mestiza. San Francisco: Aunt Lute.
Aspinall, Cassandra. 2006. Do I Make You Uncomfortable? Reflections on Using Surgery to Reduce the Distress of Others. Teoksessa Surgically Shaping Children. Technology, Ethics and the Pursuit of Normality, toimittanut Erik Parens, 13-29. Baltimore, Johns Hopkins University Press.

Butler, Judith. 1990. Gender Trouble. Feminism and the Subversion of Identity. Lontoo: Routledge.

Clouser, Danner K., \& Gert, Bernard. 1990. A Critique of Principlism. Journal of Medicine and Philosophy 15(2): 219-237.

Code, Lorraine. 2007. Feminist Epistemologies and Women's Lives. Teoksessa The Blackwell Guide to Feminist Philosophy, toimittaneet Alcoff Martin, Linda \& Feder Kittay, Eva, 211-235. Malden: Blackwell.

Donchin, Anne \& Purdy, Laura. 1999. Introduction. Teoksessa Embodying Bioethics: Recent Feminist Advances, toimittaneet Donchin, Anne \& Purdy, Laura M., 1-17. Lanham: Rowman \& Littlefield.

Donchin,Anne \& Scully,Jackie. 2015.FeministBioethics.StanfordEncyclopedia of Philosophy. https://plato.stanford.edu/archives/win2015/entries/feministbioethics/.

Donchin, Anne. 2001. Understanding Autonomy Relationally: Toward a Reconfiguration of Bioethical Principles. Journal of Medicine and Philosophy 26(4): 365-386.

ETENE. 2016. Kannanotto intersukupuolisten lasten hoidosta. http://etene.fi/ lausunnot-ja-kannanotot-2016.

Feder, Ellen K. 2014. Making Sense of Intersex: Changing Ethical Perspectives in Biomedicine. Indiana: Indiana University Press.

Haraway, Donna. 1988. Situated Knowledges: The Science Question in Feminism and the Privilege of Partial Perspective. Feminist Studies 14(3): 575-599.

Hester, David J. 2004. Intersexes and Informed Consent: How Physicians' Rhetoric Constrains Choice. Theoretical Medicine 25: 21-49.

Holmes, Helen Bequert. 1999. Closing the Gaps: An Imperative for Bioethics. Teoksessa Embodying Bioethics: Recent Feminist Advances, toimittaneet Donchin, Anne \& Purdy, Laura M., 45-65. Lanham: Rowman \& Littlefield.

Häyry, Matti. 2014. Bioetiikka. https://filosofia.fi/f/ensyklopedia/bioetiikka.

Junnonaho, Tiia R. 2014. Kohtupolitiikkaa. Feministisen bioetiikan ja queerbioetiikannäkökulmiasijaissynnyttämiseen.Filosofianprogradu-tutkielma. Turku: Turun yliopisto. http://www.doria.fi/handle/10024/97290.
SQS

1-2/2021

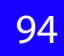

Lectio

Praecursoria

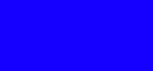


Liljeström, Marianne. 1996. Sukupuolijärjestelmä. Teoksessa Avainsanat. 10 askelta feministiseen tutkimukseen, toimittaneet Liljeström, Marianne \& Koivunen, Anu, 111-139. Tampere: Vastapaino.

Lindemann, Hilde. 2007. Feminist Bioethics: Were We've Been, Where We're Going. Teoksessa The Blackwell Guide to Feminist Philosophy, toimittaneet Alcoff Martin, Linda \& Feder Kittay, Eva, 116-131, Malden: Blackwell.

Lloyd, Genevieve. 1984. Man of Reason: "Male" and "Female" in Western Philosophy. Lontoo: Methuen.

Macklin, Ruth. 2003. Applying the Four Principles. Journal of Medical Ethics 29, 275-280.

Marsh, Jefrey L. 2006. To Cut or Not to Cut? A Surgeon's Perspective on Surgically Shaping Children. Teoksessa Surgically Shaping Children. Technology, Ethics and the Pursuit of Normality, toimittanut Erik Parens, 113-125. Baltimore, Johns Hopkins University Press.

Morris, Sherri G. 2006. Twisted Lies. My Journey in an Imperfect Body. Teoksessa Surgically Shaping Children. Technology, Ethics and the Pursuit of Normality, toimittanut Erik Parens, 3-13. Baltimore, Johns Hopkins University Press.

Nelson, J. L. 1998. The Silence of the Bioethicists: Ethical and Political Aspects of Managing Gender Dysphoria. GLQ 4(2): 213-230.

Nelson, J. L. 2012. Still Quiet after All These Years: Revisiting 'The Silence of the Bioethicists.' Journal of Bioethical Inquiry 9: 249-259.

Nelson, J. L. 2014. Medicine and Making Sense of Queer Lives. Hastings Center Report 44(4): 12-16.

Nyrövaara, Eeva. 2011. The Feminist Transformation of Bioethics: An Analysis of Theoretical Perspectives and Practical Applications in Feminis Bioethics. Teologian väitöskirja. Helsinki: Helsingin yliopisto. http://urn. fi/URN:ISBN:978-952-10-6811-9.

Parhi, Katariina \& Sudenkaarne, Tiia. 2020. Sukupuolen ja seksuaalisuuden lääketieteellisiä tulkintoja: Queer-bioetiikka ja haavoittuvuuden kerrokset historiallisissa psykiatrisissa potilaskertomuksissa. niin\&näin 2: 145-153.

Purdy, Laura M. 1992. A Call to Heal Ethics. Teoksessa Feminist Perspectives in Medical Ethics, toimittaneet Holmes, Helen Bequaert \& Purdy, Laura M. 1-9. Bloomington: Indiana University Press.

Stryker, Susan. 2006. (De)Subjugated Knowledges: An Introduction to Transgender Studies. Teoksessa The Transgender Studies Reader, toimittaneet Stryker, Susan \& Whittle, Stephen. Lontoo: Routledge.
Sudenkaarne, Tiia. 2018a. Considering Unicorns: Queer Bioethics and Intersectionality. SQSJ: Society of Queer Studies in Finland's Journal 12 (1-2): 35-50. DOI: https://doi.org/10.23980/sqs.70785.

Sudenkaarne, Tiia. 2018b. Queering Bioethics: A Queer Bioethical Inventory of Surrogacy. Journal of Ethics, Medicine and Public Health 6: 117-125.

Sudenkaarne, Tiia. 2018c. Trans- ja intersukupuolisuus queer-bioeettisinä kysymyksinä. Ajatus 75: 203-247.

Sudenkaarne, Tiia. 2019. Queering Vulnerability: A Layered Bioethical Approach. Journal of the Finnish Anthropological Society 43(3): 73-90.

Sudenkaarne, Tiia. 2020. Queering Medicalized Gender Variance. Journal of Ethics, Medicine and Public Health 15: 1-8.

Sudenkaarne, Tiia. 2021. Queering Bioethics: A Queer Feminist Framework for Vulnerability and Principles. Filosofian artikkeliväitöskirjan johdanto. Turku, Turun yliopisto. http://urn.fi/URN:ISBN:978-951-29-8507-4.

Tainio, Luca. 2013. Dikotomisesta transsukupuolisuudesta queeriin transgenderiin? Suomen Queer-tutkimuksen Seuran lehti 7(1-2): 18-29. https://journal.fi/sqs/article/view/50795

Tong, Rosemary. 1996. Feminist Approaches to Bioethics. Teoksessa Feminism and Bioethics: Beyond Reproduction, toimittanut Wolf, Susan, 67-94. Oxford: Oxford University Press.

Tong, Rosemary. 2013. Globalizing a Feminist Bioethics of Care. Teoksessa $\mathrm{Co}$ Existing in a Globalized World: Key Themes in Inter-Professional Ethics, toimittaneet Hassan, Bashir, Gray, Philip W. \& Masad, Eyad, 29-47. Plymouth: Lexington.

Toriseva, Roosa. 2017. Intersukupuolisuus suomalaisen lääkäreiden käytännöissä ja puheissa. Sukupuolentutkimus 30(1): 15-29.

Wahlert, Lance \& Fiester, Autumn. 2012. Queer Bioethics: Why Its Time Has Come. Bioethics 26(1): i-iv.

Wahlert, Lance \& Fiester, Autumn. 2014. Repaving the Road of Good Intentions: LGBT Health Care and the Queer Bioethical Lens. Hastings Center Report 44(4): 56-65.

Wolf, Susan M. 1999. Erasing Difference: Race, Ethnicity, and Gender in Bioethics. Teoksessa Embodying Bioethics: Recent Feminist Advances, toimittaneet Donchin, Anne \& Purdy, Laura M. Lanham: Rowman and Littlefield, 65-85.
SQS

1-2/2021

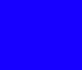

\section{(1)}

